Moorbath, S., O’Nions, R. K., Pankhurst, R. J., Gale, N. H. \& McGregor, V. R. 1972: Further rubidium-strontium age determinations on the very early Precambrian rocks of the Godthaab district, West Greenland. Nature phys. Sci. 240, 78-82.

Moorbath, S., Taylor, P. N. \& Goodwin, R. 1981: Origin of granitic magma by crustal remobilisation: $\mathrm{Rb}-\mathrm{Sr}$ and $\mathrm{Pb} / \mathrm{Pb}$ geochronology and isotope geochemistry of the late Archaean Qôrqut Granite Complex of southern West Greenland. Geochim. cosmochim. Acta 45, 1051-1060.

Nutman, A. P. 1982: Further work on the early Archaean rocks of the Isukasia area, southern West Greenland. Rapp. Grønlands geol. Unders. 110, 49-54.

Pankhurst, R. J., Moorbath, S., Rex, D. C. \& Turner, G. 1973: Mineral age patterns in ca. 3700 my old rocks from West Greenland. Earth planet. Sci. Lett. 20, 157-170.

Steiger, R. H. \& Jäger, E. 1977: Subcommission on geochronology: convention on the use of decay constants in geo- and cosmochronology. Earth planet. Sci. Lett. 36, 359-362.

Taylor, P. N., Moorbath, S., Goodwin, R. \& Petrykowski, A. C. 1980: Crustal contamination as an indicator of the extent of early Archaean continental crust: $\mathrm{Pb}$ isotopic evidence from the late Archaean gneisses of West Greenland. Geochim. cosmochim. Acta 44, 1437-1453.

York, D. 1969: Least squares fitting of a straight line with correlated errors. Earth planet. Sci. Lett. 5, 320-324.

P.N.T.,

Department of Geology and Mineralogy,

Parks Road

Oxford OXI 3PR,

U.K.

\title{
Continuation of the mapping of Archaean rocks in the southern part of the Ivisârtoq map sheet
}

\author{
Mark Brewer, Kenneth Coe and Steven Robertson
}

Field work was resumed in the southern part of the Ivisârtoq map sheet in the 1982 field season. S.R. completed an area in Kangiussap nunâ and undertook special investigations including detailed sampling for isotope studies in selected areas in more northern parts. K.C. was joined by M.B. for mapping in Nunatarssuaq so that by the end of the field season more than three quarters of the southern part had been mapped and the work is well up to schedule (fig. 12).

The ground covered in 1982 presented problems similar to those of 1981 , the main difficulty being that of assigning quartzo-feldspathic gneisses to one of the established groups. The well tried criteria have again proved to be fallible and our conviction that a large scale isotope programme is essential is strengthened. This programme is already in hand.

\section{Amîtsoq gneisses}

Gneisses believed to be of Amîtsoq affinity were reported from Kangiussap nunâ (Coe \& Robertson 1982). Their extent to the north-east of the area is now known. In good coastal 


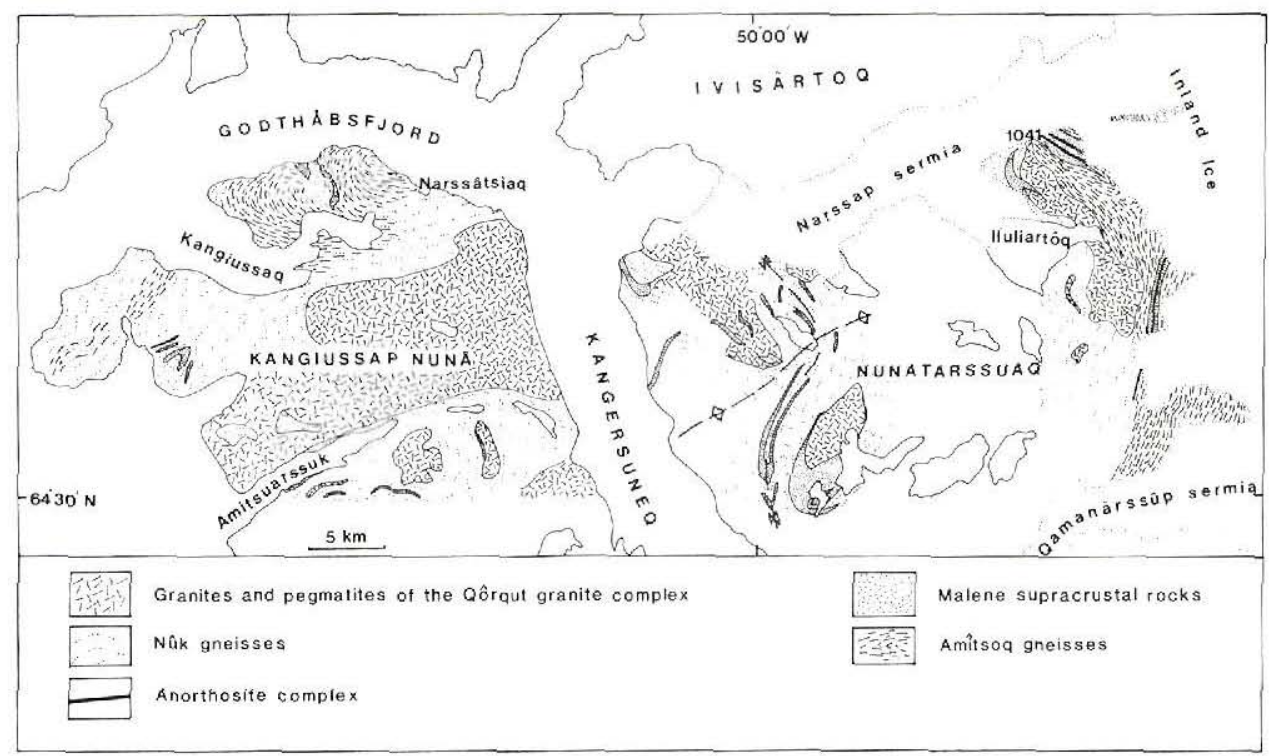

Fig. 12. Provisional geology of southern Ivisârtoq sheet, showing sub-divisions based on field evidence only. Dolerite dykes are omitted because of the scale.

exposures near to Narssâtsiaq there is evidence of substantial modification of the fabric of the gneiss. This is interpreted as reworking by static partial melting. The absence of deformation in the reworked material suggests a Qôrqut age but this has not yet been confirmed. The reconnaissance map indicates that Amîtsoq gneisses are present in the extreme eastern part of Nunatarssuaq but recent mapping casts doubts on the antiquity of these rocks. The problems are discussed below.

\section{Nûk gneisses}

The provisional division of Nûk gneisses into five units (Coe \& Robertson, 1982) needs modification. The divisions, established on field observations, remain but laboratory work to be reported in detail elsewhere shows that what was labelled Nûk 3, notwithstanding that it is typically a foliated rock, is post Nûk and has an age of $2.600 \mathrm{~m} . \mathrm{y}$. Furthermore, Nûk 4, which is variably foliated gives an age of $2.490 \mathrm{~m} . \mathrm{y}$. and is thus equatable with Qôrqut granite (see Robertson, this report). Thus the relative ages based on field criteria have been confirmed. The determination of isotope ages has made modification of the stratigraphic terminology necessary. These results point to difficulties in making correlations with type areas.

Rocks comparable to Nûk 1 are rare in Nunatarssuaq but what are deemed to be equivalents of Nûk 2 are well developed as far east as Iluliartôq. Poorly foliated to non-foliated leucocratic granitic rocks which are almost certainly of Qôrqut age and affinity are also well represented in Nunatarssuaq. 


\section{Supracrustal rocks}

Banded and homogeneous amphibolites occur widely in Nunatarssuaq but only as enclaves in younger gneisses. Homogeneous amphibolites are more abundant. The amphibolites vary in size from little more than hand specimens to mappable units which define folds, and which because of the development of mineral lineations are useful in elucidating structural development. Commonly associated paragneisses are often quartz-rich, with plagioclase and variable amounts of garnet, sillimanite and cordierite. The lithotypes grade from semipelitic to psammitic when they may have a tonalitic composition. Compared with adjacent areas there is an unusually high proportion of paragneisses to amphibolite and since the two supracrustal types which share a common structural history are closely associated in the field it follows that this proportion must be not only real but also original. It is not yet possible to determine whether the preserved rocks represent a dominantly clastic succession with occasional basaltic lavas, tuffs and sheet intrusions, or whether it has formed from a volcanoclastic succession which alternated from acid to basic. The first interpretation is favoured at least where the quartz content of the rock is very high.

\section{Anorthosite complexes}

Anorthosite enclaves were reported from Nûk gneisses in Kangiussap nunâ (Coe \& Robertson, 1982). Similar enclaves are rare in Nunatarssuaq but in the extreme eastern part close to the Inland Ice there are two anorthosite complexes. In the north-east, a layered complex consisting of metagabbro, leucogabbro and anorthosite occurs in two sheets trending north-north-west. These are separated by acid gneisses with very abundant anorthosite enclaves (the boudinolith rock of Stainforth, 1977) and are flanked to the east and west by very distinctive flaggy amphibolites. The symmetry of the whole is that of an isoclinal fold but there is no closure nor facing evidence to help classify it as antiform or synform. The relations between the gneisses and the anorthositic rocks in the core of the fold are unambiguous, and hence the simplest interpretation must be that the fold is an antiform possibly localised by the injection of the parent magma of the gneiss. The symmetry shows that the anorthosite and amphibolite were deformed together and nowhere was discordancy observed between the two. There must, however, be some doubt about the genetic relationship between them. Elsewhere in the Archaean block of southern West Greenland, anorthosite sheets inject Malene amphibolites (Escher \& Myers, 1975) and similar relations may hold here. On the other hand, if the amphibolites and anorthosites are cogenetic their relationship with surrounding gneisses becomes important. Unfortunately, because of patches of permanent ice and scree, the actual contact is rarely visible and where it is exposed a clear fault relationship is displayed. Nevertheless, the style of deformation and the relative strain developments in gneiss and amphibolites suggest that the gneiss is the younger rock. This view is supported by the local occurrence of enclaves in the gneiss of both amphibolite and paragneiss. Thus the amphibolite and paragneiss are assumed to be Malene supracrustal rocks, while the anorthosite is somewhat younger and the gneiss is of Nûk affinity. Except in the core of the fold there are no enclaves of anorthosite in the gneiss, but there are rare discordant amphibolite dykes both to the east and to the west of the complex. These are referred to below.

The anorthosite has features in common with other complexes in southern West Green- 
Fig. 13. Contact relations between anorthosite and cognate amphibolite dyke, north-east Nunatarssuaq.

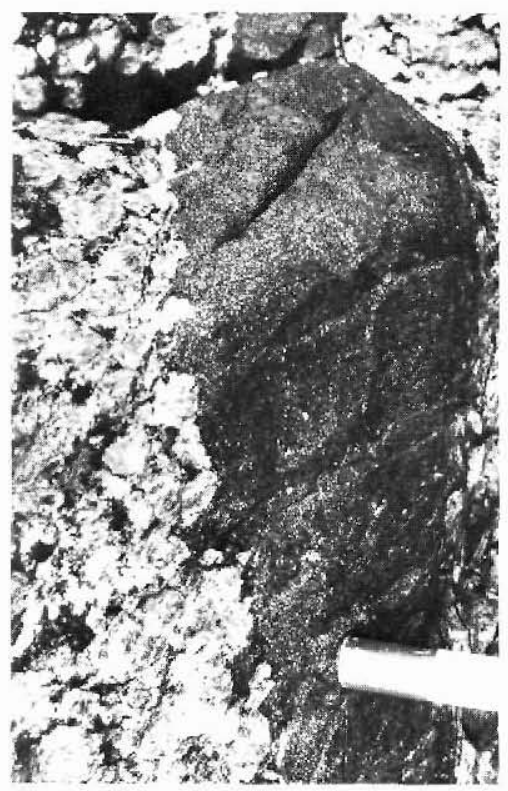

land. The grain size ranges from medium with rimmed plagioclase crystals which are pea-sized to very coarse with plagioclase grains a little less than tennis-ball size, loosely packed in a mafic plagioclase-amphibolite groundmass. Such loose packing, frequently 'matrix supported', is not an uncommon feature in anorthosites but has not been reported. It suggests movement into place of a slurry of large plagioclase crystals fluidised by an inter-precipitate melt of basaltic composition. Both flotation of early formed crystals and rhythmic crystallisation of the type suggested by McBirney \& Noyes (1979) might be expected to lead to a 'grain supported' texture.

Amphibolite dykes occur but are confined to the complex. These are comparable to the cognate dykes described from many other layered bodies (e.g. Hess, 1960; Sharpe, 1975), and in a rare example from the summit 1041 the relation between the dyke and the matrix between the feldspar crystals suggests that the dyke was formed by segregation of matrix material or at least that the dyke material was emplaced into unconsolidated anorthosite (fig. 13).

A feature of the relationship described above but not emphasised is that the anorthosite, always regarded as a deep-seated rock crystallising under high pressure, is injected into amphibolites which are associated with paragneisses. Either these rocks were deeply depressed in the crust before the emplacement of the anorthosite and the beginning of the injection of granitic gneisses, or the anorthosite was injected, perhaps as suggested as a semicrystalline mush, into relatively high crustal levels.

The second anorthosite complex lies close to the Inland Ice in an area, difficult to reach being confined on its west side by a major lineament. The lineament has been deeply eroded and now marks the course of a fast flowing stream. The anorthosite shares some features with the complex described above; in petrography it is similar and the associated amphibo- 
lites have comparable field features. Later gneisses are, however, rare and their place has been taken by massive non-deformed pegmatite sheets. Relations between anorthosites and sheathing amphibolites and gneisses are not easily determined, mainly because of the fault and extensive spreads of moraine and fluvio-glacial debris. A narrow wedge of gneiss at the southern end of the main outcrop contains amphibolite sheets in some of which there are plagicolase aggregates or anorthosite enclaves. These could be interpreted as Ameralik dykes. Similar dykes cut the anorthosite itself. The critical interface between anorthosite (or strictly amphibolite associated with the anorthosite) and the gneiss is lined by a pegmatite sheet, and structures in gneiss and amphibolite are parallel. Rare outcrops on the eastern side of the complex also show gneiss with dyke-like amphibolite sheets but these exposures are isolated by moraine. Near the northern end of this complex there is repeated inter-sheeting of anorthosite and gneiss. The inter-sheeted mass is strongly flattened with development of boudinage. The interrelationship is presumed to be due to injection of anorthosite by gneiss. Gneisses in adjacent outcrops are cut by abundant amphibolite dykes.

The total interpretation of relations must be tentative, but a clear case can be made for an Amitsoq affinity for some of the gneisses with anorthosite injected into them. An alternative interpretation must be made if all the gneisses are deemed to be contemporaneous, since it must then follow that either this anorthosite complex is pre-Amitsoq in age or, notwithstanding the evidence of the dykes, the gneisses are Nûk.

Features of the anorthosites have been given in detail partly because of their intrinsic interest but also because of their significance in relation to the gneiss problem referred to above and the geological evolution of the area.

\section{Qôrqut granite}

Mapping has revealed a greater area of Qôrqut granite than was originally suspected. It is very abundant in the central part of Kangiussap nunâ and substantial areas are known or suspected in Nunatarssuaq. In Kangiussap nunâ two groups have been established, an earlier group consisting of granites (rarely foliated) was previously reported as Nûk 4 . The later group consists of granite and pegmatite sheets with some aplite components. Both are multiphase. Wherever the Qôrqut granite is present its multiphase nature is obvious. In some localities up to four stages of intrusion can be seen with sheets from a few centimetres to about $50 \mathrm{~m}$ thick making a complex network. In some areas flat-lying dilationally emplaced sheets (with rare risers) dominate, but in northern Kangiussap nunâ the sheets are mainly vertical. In other areas no single attitude of sheeting is dominant. Banding mainly due to biotite concentration and orientation is variously developed and problematic in origin.

The later pegmatite and granite group is also found as complex multiphase sheets, coarse-grained, pink feldspar granites having been emplaced between periods of pegmatite injection. Again vertical and horizontal orientations dominate, with the latter the more prominent. Locally the mineralogy is spectacular with potash feldspar crystals a metre long. Magnetite and allanite are locally abundant.

Only rarely do members of the two groups occur together. Such a display is in cliff exposures in south-west Kangiussap nunâ. The Nunatarssuaq representatives are of the second group and although pegmatite is commonly developed the grain size is less spectacular. 


\section{Structure}

A model for the structure of Nunatarssuaq has been based on the distribution and attitude of supracrustal rocks and, to a lesser extent, on the orientation of foliation surfaces in granitic gneisses. A broad concordancy of these structures suggests that, as in other areas, the preserved structures were imposed or superimposed on all rocks during and after the injection of the parent magmas of the Nûk gneisses.

In the eastern part of the area the foliation surfaces define a large-scale gentle fold with an axial trace about east-north-east. Dips are to the north-east in the north, swinging to easterly in the southern parts. Isoclinal folding of the anorthosite complex in the north-east and a rather steady plunge of linear structures (both mineral lineation and small-scale fold axes) to the south show that this open folding is superimposed on an earlier phase of deformation. The earlier phase is more obvious in western Nunatarssuaq where supracrustal rocks define isoclinal folds with hinges preserved in areas of favourable exposure. The axial trace of the later stage of deformation can be mapped throughout most of the area. This interpretation is consistent with that of Hall \& Friend (1979), the two stages equating with their second and third stages. No trace has been recorded of their first stage.

In the extreme south of the map sheet (and south of latitude $64^{\circ} 30^{\prime} \mathrm{N}$ ) Malene rocks in Nûk gneisses define isoclinal folds with axial traces about east-south-east. It is not yet possible to say how these relate to the extreme north of Kangiussap nunâ where old rocks lie in the north-south belts in the north and west but trend about north-east to south-west in the east.

In Kangiussap nunâ structures are controlled by the later granites. In central Kangiussap nunâ Qôrqut granites dominate and give a substantial thickening of the crust.

\section{Comments on the classification of gneisses}

Field criteria used to distinguish Amîtsoq gneisses from Nûk gneisses vary in character and in reliability. McGregor's (1973) definition of Amitsoq is that the gneisses are cut by Ameralik dykes. Unfortunately, in places, the characteristic dykes are not present or not abundant and the situation is complicated by the occurrence of a variety of Intra-Nûk dykes. In the southern part of the Ivisârtoq map sheet Intra-Nûk amphibolite dykes are abundant. These are similar in field features to those described from the Buksefjorden region (Coe et $a l ., 1976)$. Only rarely do the dykes in Ivisârtoq occur in swarms; even less frequently do they have distinctive plagioclase crystals or clusters of crystals which are the $\mathrm{C}$ type dykes in Chadwick's (1981) classification. In north-east Ivisârtoq Amîtsoq gneisses, classified by the presence of Ameralik dykes (Hall \& Friend, 1979; fig. 14 this report), have extensive outcrop. Gneisses and some of the dykes are cut by sheets of grey gneiss. These must be regarded as Nûk sheets yet they in turn are cut by a dyke which in the field is typically Ameralik type $\mathrm{C}$ amphibolite with plagioclase clots. This is a clear indication that dykes identical in field features belong to two generations, and hence have much diminished significance as time markers or even as being characteristic of one particular gneiss type. Secondary criteria for recognition of Amitsoq gneiss such as the occurrence of inclusions of Akilia association enclaves may not be expected in granitic sheets that were emplaced in there is no a priori reason why these facies should not be present in any younger intrusion. Akilia association enclaves may not be expected in granitic sheets that were emplaced in 
active shear zones or tensional fissures, but clearly where enclaves are found in the gneisses they may be of rocks of any greater age. In this respect the anorthosite complexes are important. Most of the exposed anorthosite sensu lato in the Archaean of West Greenland demonstrably post-dates Malene supracrustal rocks. Enclaves of these complexes in gneisses must prove their hosts to be Nûk age or younger. However, the possibility of a pre-Amîtsoq age for some anorthosites including those of Nunatarssuaq has been suggested above, and Nutman (1982) has described anorthosites and Amitsoq gneisses with ambiguous age relationships. Equally uncertain are criteria based on the deformation. Structural features can often be used to establish relative ages but rarely can they be relied on to distinguish Amitsoq gneiss from Nûk gneiss. It is considered that a geochemical programme should be followed with particular attention to isotope geochemistry. In many parts of the Ivisartoq sheet, cumulative field evidence for classifying gneisses is compelling but this should be confirmed by laboratory studies.

\section{References}

Chadwick, B. 1981: Field relations, petrography and geochemistry of Archaean amphibolite dykes and Malene supracrustal amphibolites, Northwest Buksefjorden, southern West Greenland. Precambrian Res. 14, 221-259.

Coe, K., Compton, P. M., Stainforth, J. D., Vines, K. J. \& Wells, P. R. A. 1976: Investigation of Precambrian rocks in the Buksefjorden region, southern West Greenland. Rapp. Grønlands geol. Unders. 80, 77-82.

Coe, K. \& Robertson, S. 1982: Mapping of Archaean rocks in part of the Ivisârtoq sheet. Rapp. Grønlands geol. Unders. 110, 63-67.

Escher, J. C. \& Myers, J. S. 1975: New evidence concerning the original relationship of early Precambrian volcanics and anorthosite in the Fiskenæsset region, southern West Greenland. Rapp. Gronlands geol. Unders. 75, 72-76.

Hall, R. P. \& Friend, C. R. L. 1979: Structural evolution of the Archaean rocks in Ivisartoq and the neighbouring inner Godthaabsfjord region, southern West Greenland. Geology 7, 311-315.

Hess, H. H. 1960: Stillwater Igneous Complex, Montana. Mem. Geol. Soc. Am. 80, 230 pp.

McBirney, A. R. \& Noyes, R. M. 1979: Crystallisation and layering of the Skaergaard Intrusion. $J$. Petrol. 20, 487-554.

McGregor, V. R. 1973: The early Precambrian gneisses of the Godthåb district, West Greenland. Phil. Trans. R. Soc. Lond. A 273, 343-358.

Nutman, A. P. 1982: Investigations on amphibolite facies orthogneisses, amphibolites and leucogabbros on Akugdlerssuaq, inner Godthåbsfjord. Rapp. Grønlands geol. Unders. 110, 72-77.

Sharpe, M. R. 1975: Anorthosites and serpentinites of the Faeringehavn area, southern West Greenland, and their position in the regional chronology. Unpubl. Ph.D. thesis, Univ. Exeter.

Stainforth, J. G. 1977: The structural geology of the area between Ameralik and Buksefjorden, southern West Greenland. Unpubl. Ph.D. thesis, Univ. Exeter.

Department of Geology, The University, Exeter EX4 $4 Q E$, Devonshire, 